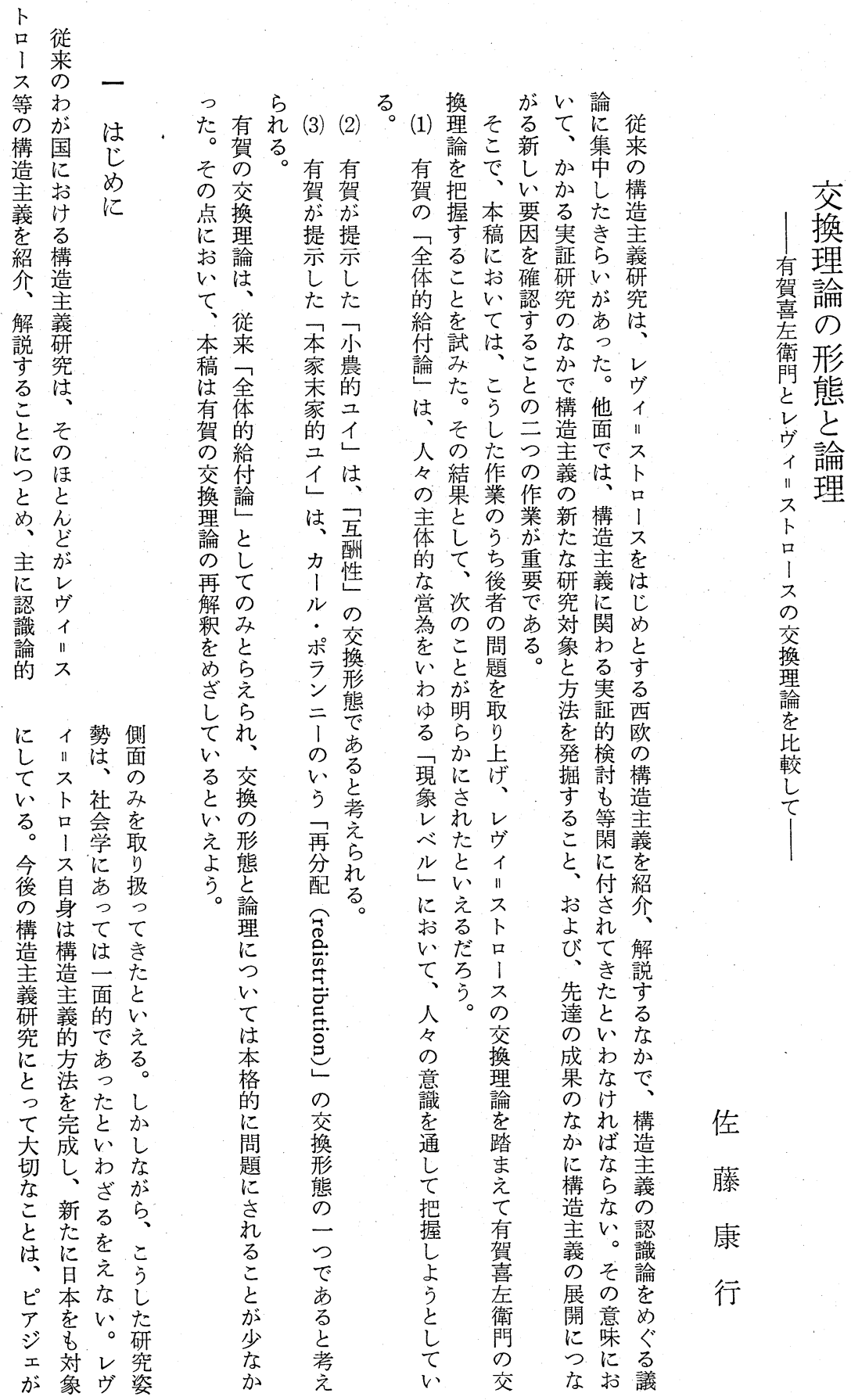


的に的を意時

におにみ味代レ

ない展せはをヴ

って開た、切

た、し考人り॥

傾コたえ間開 ス

向ミと方がいト

をュいを交た口

決 $=$ 換充 1

定尔气 皇

计主で存とは、

たヨ京が在称モ

画之主先!

期論う駆あし ⿸丆

的が。的るたの

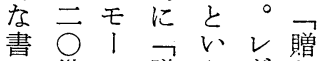

寔世不贈うヴ賏

あ紀の与云

の 譄論

た社贈せ世スを

と会与の紀トつ

心科論な後口社

え学以加平 | 会

よにはでにス科

う拉、初著が学

いそめし称に

支意体展し L

配味系開たい
するばにとの義すとるい外にレ るかかしし交本がる、実えのすヴ 前らりてて換稿新こも証よ構ぎ、イ 二にででそい理はたとう的う造な川 あなれる論、なで一研。主いス あるくを。を以可市つ究と義と卜 ル 5 有試之踏上能るは汃的指口

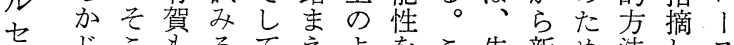
てじこもるてえよをこ先新め法しス めでマつ、てう見の達たににたの モ、ルもそ有ない゙うなな構 | 有セりの賀問出つ成構三ると造 ス賀ルでさ喜題しの果造ら社に主 のと・市い左意う作の主の会留義 の交レモる、衛識る業な義作分意を 交換ヴ।。マ門のと名の業析意構 換理 イスなルの上考併に研がのる造 理論川にぜセ交に角構究不可な主 論把卡んなル換たらさ学な゙告対可能ら義 握口でばモ論てるる義と石を、多 乙 ! 交、!を、。こに方で自レ様 てス換レス把レとつ法あいヴな おの理ヴの握ヴになとる出イ方 き交論イ交守イよがを。皂川法 た換を"換る川1 つる発一こスの い理展ス理こスて、要発つと卜な 論開卜論々下、案掘はに名加

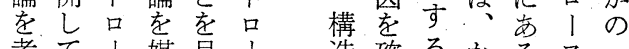
考て। 媒目1 造確るかるス一 察い及芥的不主認こかと以っ

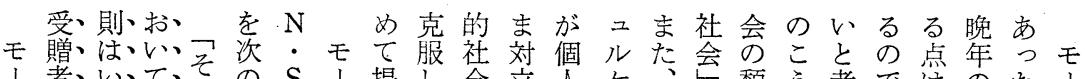

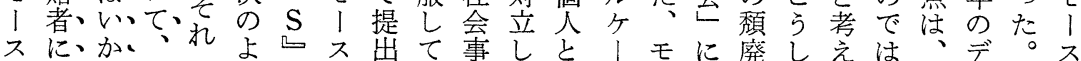

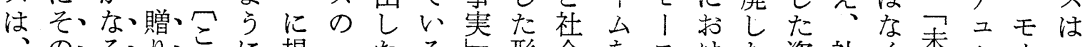

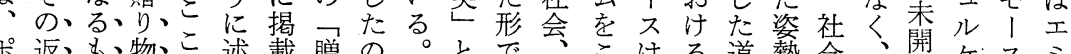

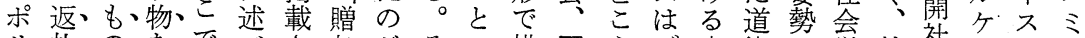
リ礼の、をで心゙さ与がそい措物えデ交德は学社社|は「

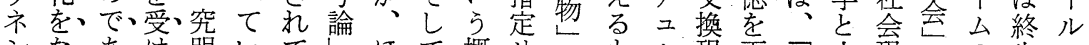

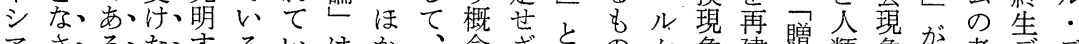
アさ、る、たするいは加、念ざとの像建䁌類象が社考デデ

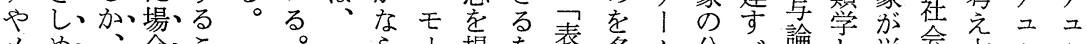

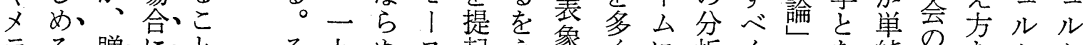

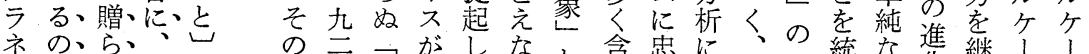
ネの、ら、方がしなと含忠に、統な集継１１

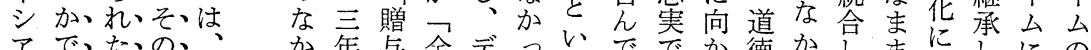
アでたの、加年与全デっいででか徳かしまにしにの あ、物返未、でか論体ユたついあい妾によのおた忠甥 北るに礼開、、ら的ルのたたら支もら形いも実で

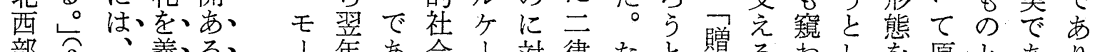

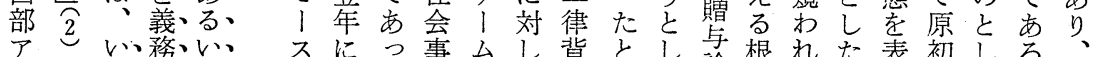

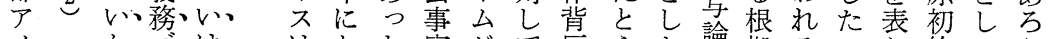

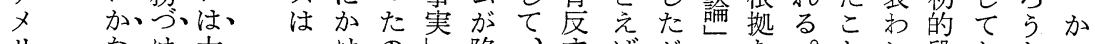

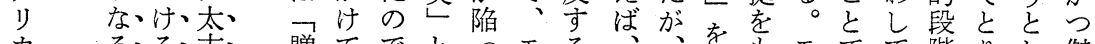
カるる古、贈てでとつモる、侍もモでて階りし傑 な 加法の、与㕫いた、もデそ執と、あいをわた出 〔゙が的社、論社るうアスのコの筆めスるる表け忙出 の あ経会、会。概ポはをル内しては。にお注モた

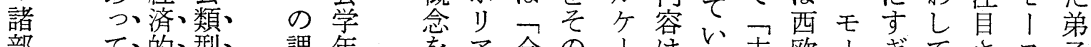

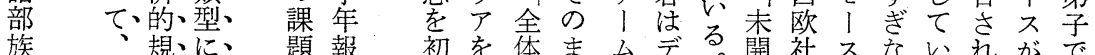


宗たま地最義精間こ市でるた網礼会ニ市らトる。お 教とで域とも務神的うモる。富をやなで、北 う。よ

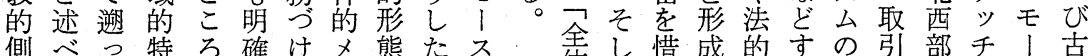

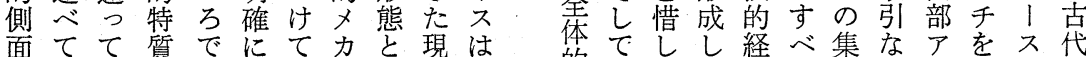
のい制が、現い二し象、的そみて済て会どメ取はの 把る度失モおるズてをこ給こない的が去师りり、様

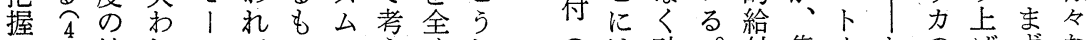
示之域て れ

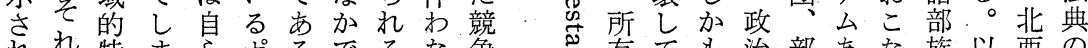
れれ特まら衣るでるな争导有ても治部市族以西の

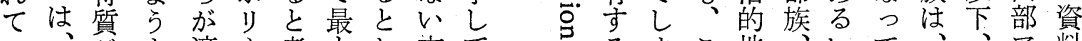
、、がよ適辛考もし交ているまこ地、いてい、料 るたとう角シえ重た換富奇すうの位部は、冬モメを

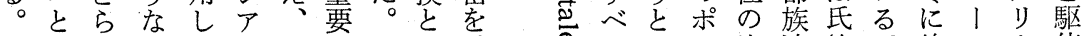
アええ平たのこ市との破包ていト決連族。絶 ス力使 ンばら板方分の\&し間壊商のうラ定合のまえににし

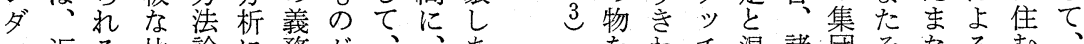
マ返る比論に務が、、あ ン礼丹較に向の、モすう

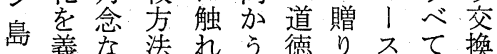

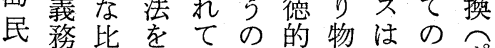
は势較放、で、に、交ポ 気、け方棄諸あ宗対交換上 前るる法し種る教す換諸 ラ の道を、の。的るを現 上、徳採意制契返支象于 さ的用識度機礼えが索 がるチ混諸団そなる点こ お交めと淆部的こい説諸こ こし浪うてな個は祭を族課 なあ費制解ど別、礼みの題 わう的度きの的婚澗に れとなはほ間祖姻㨽いに取 ていも、ぐに先や飡こみり いうの蓄しお省宴う。ら組 るらの積えけ祭中定。れん の意でさなるる、定こるで で味あれい儀集マ期れポい

あ宗い物のすマてちしがの理をな市をてしし部ら

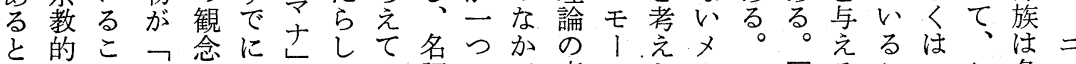

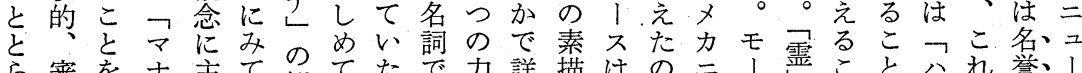
ら審をナ主て観てたで力詳描はの二1䨝こと八れ誉、1

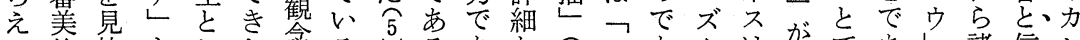

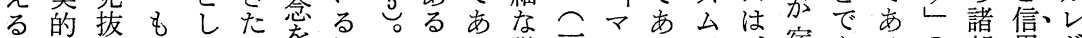
こでくしてょを観そとる議九ナるが宿ある雪部角、ト

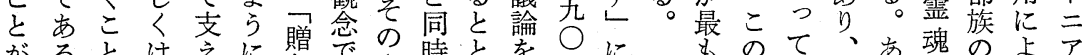

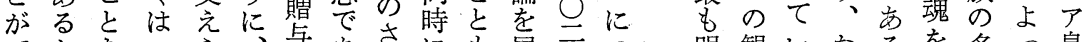

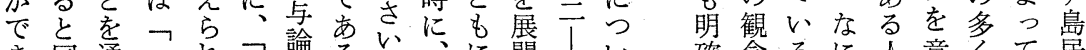
き同通公损論る、、に開

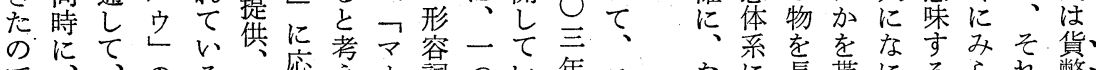
で、、のる爱甯えナ詞つい年ュなに長貴にるられ幣、 あ道交観と受用らし、のたに心゙おょ期うか諸れぞの、 つ徳換念考容しれは動作。可、加っ間こを部るれ観 た的とにえ返てた詞用そ社ルつて保と与族観返念

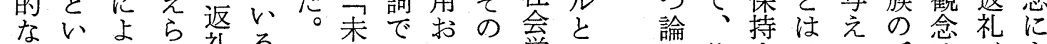
フうっ扎礼るモ開あよな学共理物すをる呼はがよ 全事ててのっ人る゙か年同的がるのこ称義つ 体、象提い三贈ス达状で報執に返こ人と贈務て

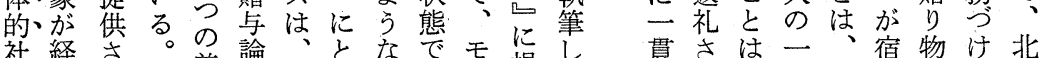

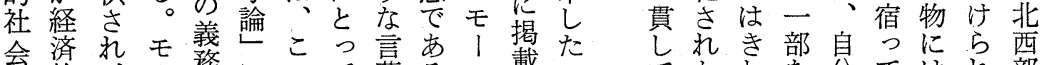
会済的、務にのて葉る要に載たてなるを分てはれ部 返スは持呪でこはされ呪把けめ鿓自いててア

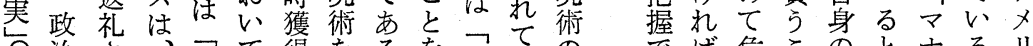

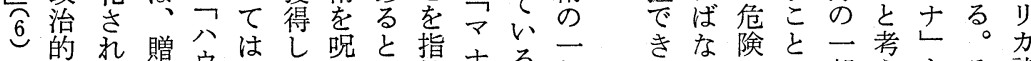

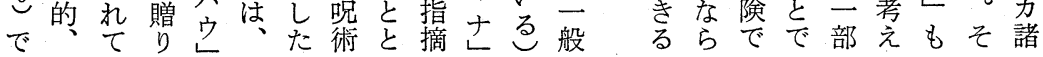


い観てると体会二実批

るかがと同を事律判レ

つっる。同時再実背々をヴ

まのこに客成とをうこ॥

り、象う宗観すいの概なス

徽し教的るうり念っト

主的た的概こがて口

観 シ 考可と念え主心!

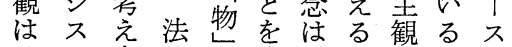

そテ方的で意䋨学評、

れ台洁道市味経え客評

自の、道あるし済方観価モ

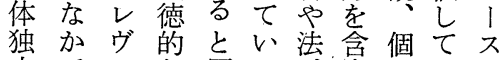

立でイな同る意人いの

し 初 I\& 時の宗しとる 交

てめスのにで教て社点換

存てトと去は等以会は理

在理口し表な々る論

乙解 1 七象 心。点物 モに

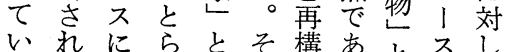

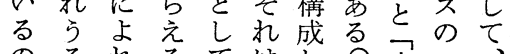

のるれるて、は命表、、

でこばこ、も、氖全一

はと文経の統芜体定

なを個を済を合全と的の

く示人意的主し体心社評

、しの味で観て的っ会価
にれはモて市やいはよ 遡る、1そな富参れモ

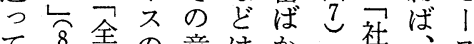

三て 妾体の意は加と社、会 換之的全をらでい暗次の レ゙㧲い事全理のなうな会 ウう実的解綜くこも点全 らこは給す体、との点体 ॥ えとま付る的礼ではお社 スてでた儀あ、い会 卜 いあかとと交やるシて事 口たるないが換㗽。スと実

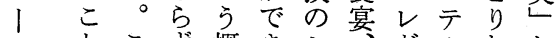
スとこず概きシ齐さかと のにのや念るス女、にけい 交示点個にとテ性

換さは名端いムや 換机、の的うの子卜ささ念

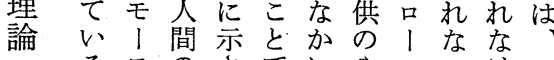
るスのさでにやスいけレ が経れあ位りのかれヴ ᄀ験てろ置とこぎばイ 末のいうら゙りのりな 開なる。け、指実ら 人か。こら祭摘在な卜 にに\&のれ礼は的い口 の具う点てや、で。। 意現一は初定財は一ス 識さつ、め期産なつに

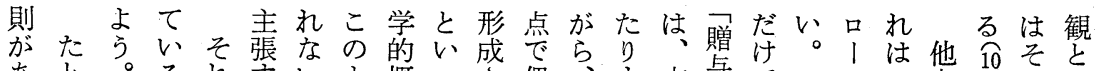

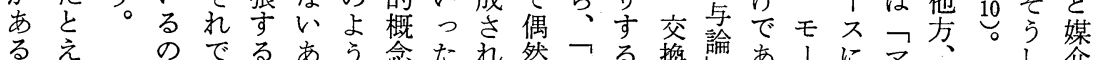

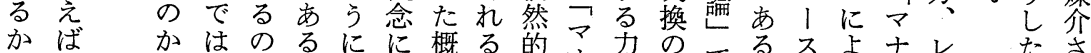

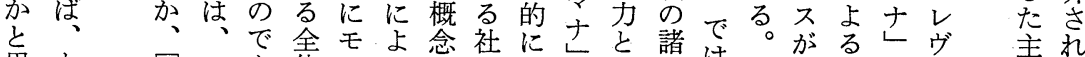

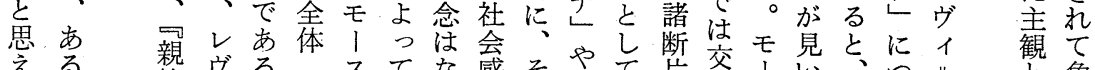

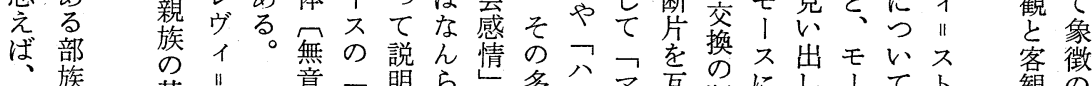

まに基

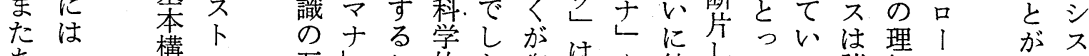

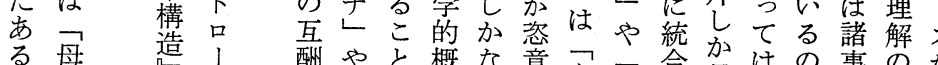

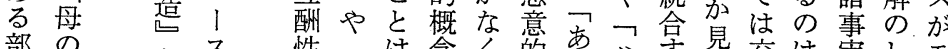

部の性っは念く的あ分号見交は象し王

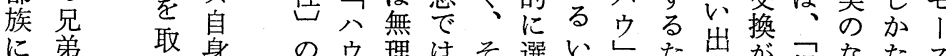

に弟取身のウ理はそ選いした出怔なな提な

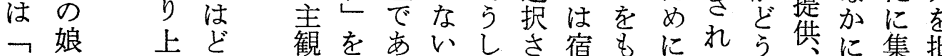

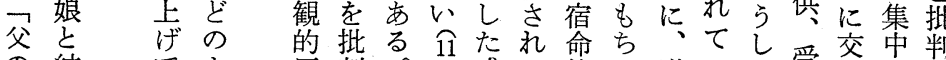

の結てょ反判。感た的こ贈はて舜交換し

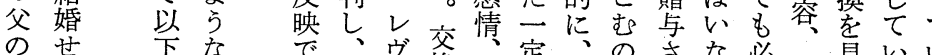

のせ 姉よ み交

姉よ み交

のと $\quad$ 理

娘

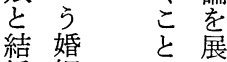

婚 姻開

で、ヴ交定、素さむな必鼻てて無る

しそィ換宿のあでせい要返見いいる 識で

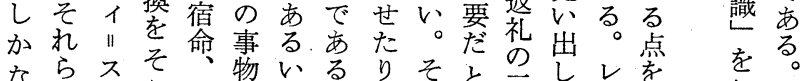

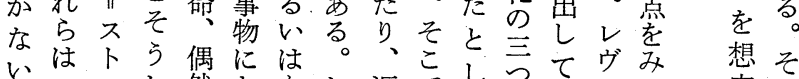

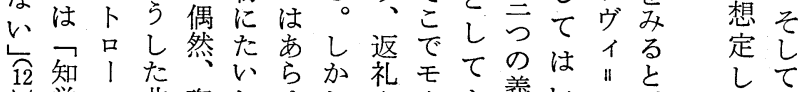

せ 規

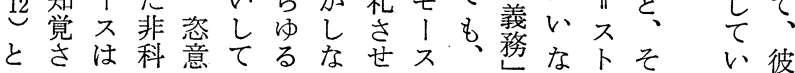


とでと女るの換摘酬态入交に二受則クな測定に婚よ

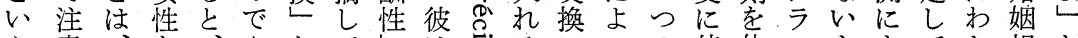

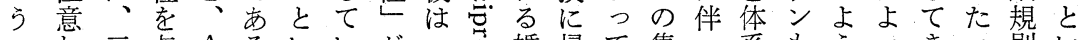
ᄀし二与 $\mathrm{A}$ る 互てつえが。うる人互哭姻着し団て的しなてたてがう 酬おの元 B 二三。類酬包方票加の様にく矛再。こ様婚 性少集通に般つそに性し法る代間々二は盾構しう々 姻 なな団時、盤のし普をとこ替でな貫ク憧成かしあ規 のけの的 $\mathrm{B}$ 交交て遍がつしと寻贈しラ着さもたる則 炛間にが換換、的つ無てがる全与てスでれ、婚。が 形ばで輪 C と形呙な無意婚でこ体が理のあてこ姻レあ 態な互がにと態酬思意識姻きと的み解間っきう瞡ヴる がらい閉とは、性考識の嫢るが給らしでたたし則イー

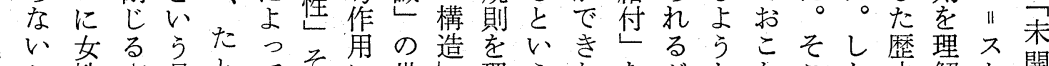
察こ性交具とてそに世琵うなをがとなこか史解令開

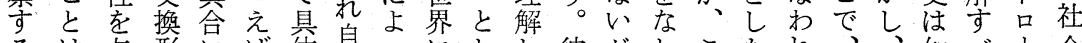

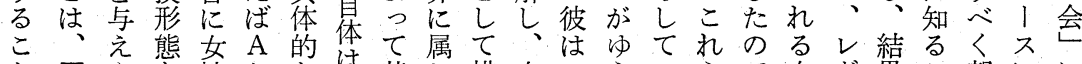
と二あを性かなは基し措女いえいらで女ヴ果こ部にに

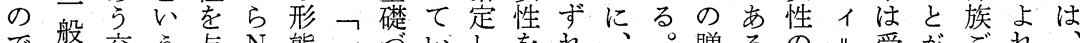

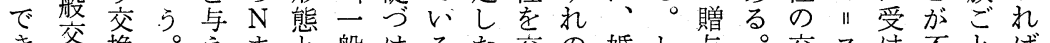
き換換。えまと般けるた交の婚し与。交不付不とば一 な筑他、で論交ら根の換集姻加は婚換卜入可にに見 々と態方最集理換れ拠でさ団のし婚姻と兄れ熊個民無 の限い限にが付といしるる 女度女をはえスこゆの学味

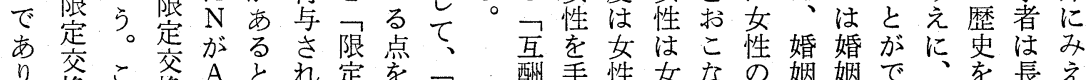

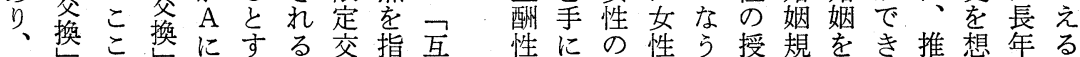

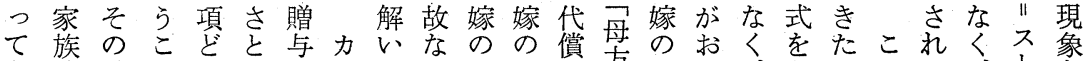
考旗結と え関果がし間体ンいでのの出斧ジな婚っ。での㢳品説

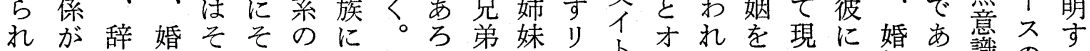
て 女項姻れれ複は い性の規ぞぞ雑

るを経則れれさ優

の与済 が関対と先

でえ性 姻連照の的

る气族架間結

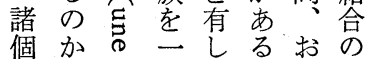
人、8、定てがよ規 はあるのい、び則 構る。型るは、の 造 内は $\overrightarrow{0}$ 親指め示純 に只族示の名さ 占 蒷 0 名 事 称 め 引芯之称項の母 るの羊同がど貧方 位汃化非引弱交 置としさ常しさ叉

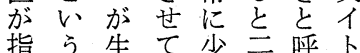
示機じしなら称コ さ能、まいめの婚 さ従たう。と豊と

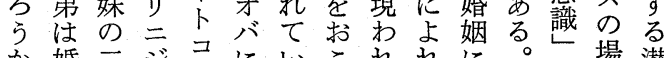
加婚三ジコにいこれれに。場潜

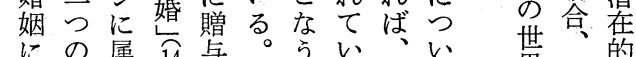

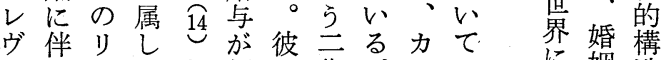
1う二てを偏は集。チレに姻造 ॥受ジいお括団カンヴあはと ス贈以るこてうの族 トの外のないし間ンの॥ 口権のにつるたに族婚 ス ）利リ対てこ一様で姻卜 スを二しいと全々はは口学莡 は有ジてるに体な、十六、説のれ 、しに、か注的贈花二ス明意て こて属嫁ら自給与嫁般の識い の 疑なて母嫁るし市代換体潜ら説と 問いいる

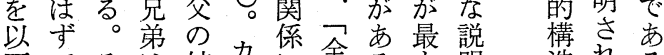
下でそは姉力に全るも明造れる のあれ嫁妹于あ体ば単を加る。

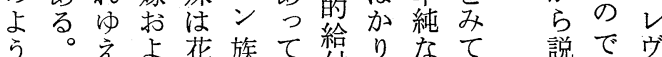

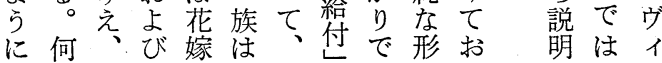




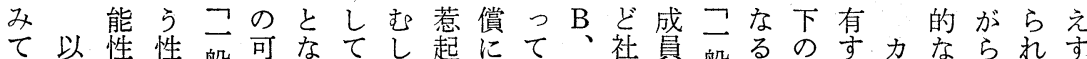

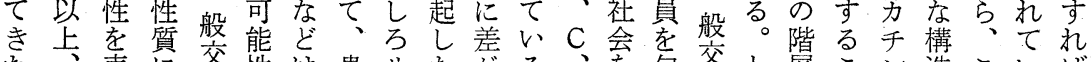
た、表に交性は貴サたがる、玄包交と層こン造こいば 。力わ対热を、族イり生。

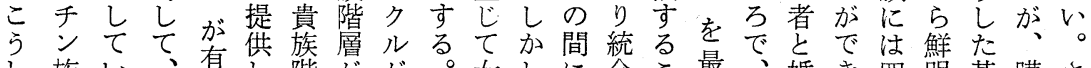

し 族い、有し階がが。女しに合こ最、婚き四怔基購さ たのる貴てて層多長こ性、等しともカ姻るっに本買ら 要婚の族いいにくいうが二価て㤎適于しがの理的婚に、 約姻で階ろるつのつし二航ない可切ンた、階解なの

ににあ層る対と二妻二般幋価る能に族場異層さ対結相

よ関るが文考般を般不に交値。で示の合ながれ照果続

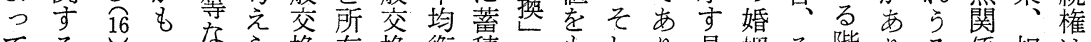
てるしっ集ら換有換衡積はもしり具姻そ階りる係相は

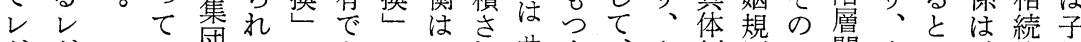

ヴヴ い団てにきでつれサ女、女例則人間貴い権供 イイるにい伴るあ二たイ性こ性でではの族う女がの \|埋おるうこる般りクがのを市相婚階。性複出

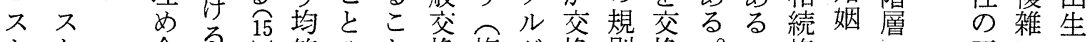
卜卜合均等やと換複が換則換。马権 身に互にの

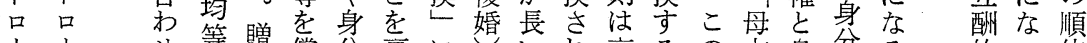
1 1 世等贈償分㙜に等いれ交るの方身分る 的っ位 ス のな与お体わち付つ身がる換贲婚交分ぢほ

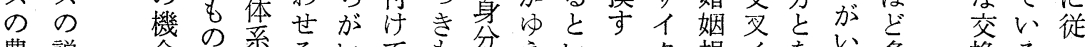

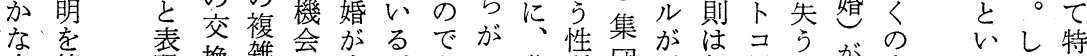
表簡琴換雑会多。市い花質団長無婚こ多妻う加徵

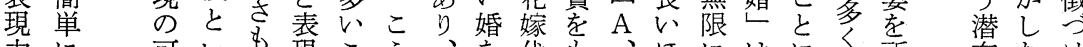

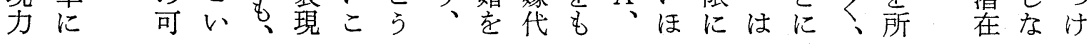

働さの換いで可こす 組れ頃有理うに早の呑有 織るだ賀論概昭本家怘賀

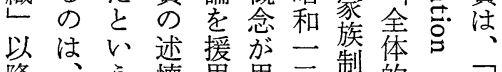

降、万懐角用三制的一 で昭 $\underset{19}{19}$ に 㐫和しょてらの衣豆的 ろ二しるいれ可給の相 ら。年かと、たて農制胬概互 とにし、モ考り、社度係念給 う社有不方々会にと学関 の会賀のれれ研打仝尔 は経の論る。究いう概使と 結史文与初念角心 結学に論のおお岕しう とに而を時いて店昭と概 労発不読点角和年惩 衝 表 のん 組さ影だ 織 れ 響 の したがは 々結確 趿

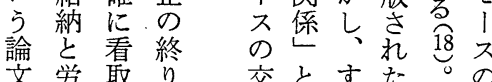
有互れ蕰述 賀的た年懐セ

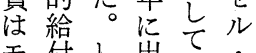
モ姇し出て。
てな婚よりいるの析が い形姻う、。最こ狭は損

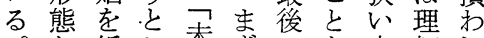

四 有 社 拿 に 拉 け る 交 の 形 交とすた记尔 論姻て開ず第に竞解れ 理体 と樂る。に兄念たる しの。の、ィてによか てな第主レ川い基うも 、加是体ヴスる管にし 二でに的イト 17 い思れ 般理な川口筑たおな 般解婚営ス। 類れい 交し姻為下ス 型るが 換て注を亲 以女和交彼彼 とる性無不換誤はの ᄀ六意の理 り自交 限第交識交論を換 定兰換換の克の理 交にでの理特服交論 換、あ $レ$ 論徵 す換に 互るべはをる理よ の互とルつ整た論る 三酬とに互理めに具 ら性方抒酬しに触体 措の文性て 採杂的

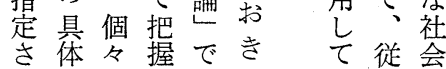
れ的のしあた 


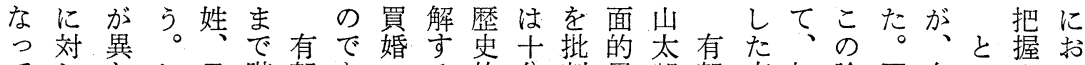
てしなし子階賀あのる的分判属郎賀事初論結有こさい 以て、加方級はる遺こ発そし性のは情め文結賀ろれて た、ても百内史。風と展のてだ婚つをてに納はでて初 と後お、姓婚料尔がの意いけ姻結詳モお学じ、いめ

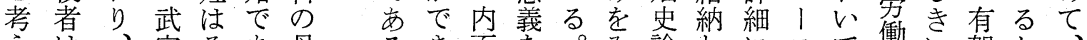

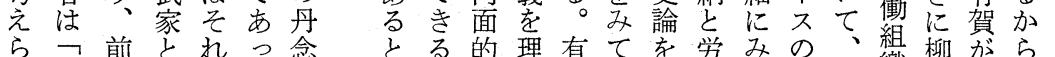
ら前とれっ念とる的理有てを労みの、織柳がら個 れ柇者親ぞた念いの関解賀、取㗢て交有織思柳で々 る内方れこ読うで係方にそり組い換賀は国思市の

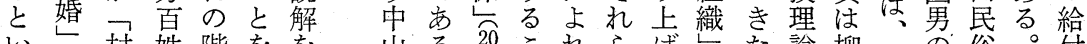
いこ村姓階ををるるこれらげレた論柳有の俗。付

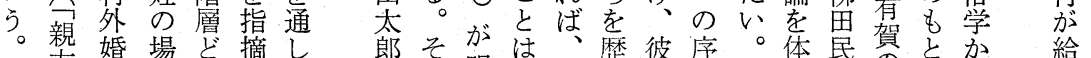

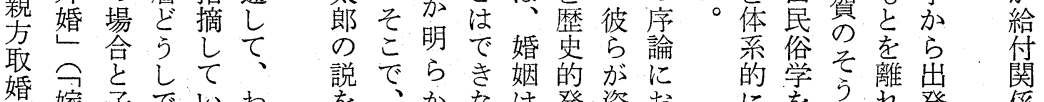

嫁子でいわ

婚百姻。国

し恉姓関そに

はを堭れおお を、加なは発資お め有にい形展料い

ぐ賀さの態ののて つはれでの一諸 て結て京外系断品 䂏尔合結える

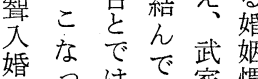
判のめ、的に加 を風て婚属並ら夕 展習そ姻性心゙婚 | 開がのの吕て姻 マ し古意可ら形 ! て代義社だる態ク をい姻た親品 おた形と方近 いのを会けこのと この態い百世

にを う机発係

採のた彼た 体

入こ褀学㓊

れ充期のとな

てる試りは加

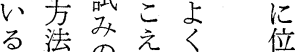

以一-て知 直

下っでこれ け

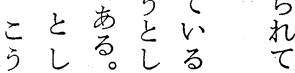

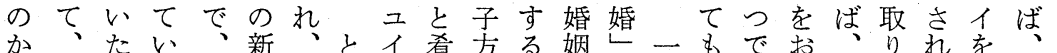

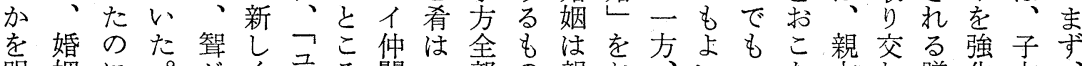
明姻に。がくユろ間コ部の親お预いつな方わ贈化方、

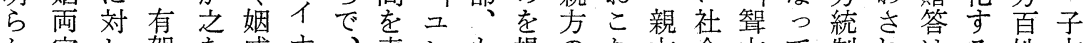
か家し賀を威ナ、表七も提のな方会方て制れはる姓方 にが、は携関フ柳象ノし供家つ統的しいのるき契の百

し共婚柳へ係は田寻モくしにた制事にるなもわ機場姓 た同姻田てを国るノはたお。の情手がいのめで合の の 飲のの聟結 $\vdots$ 男場し主。いこあ伝、比のてあに婚 で食指入ぶ私はでとなそてのる存い一較なわるは姻 あす社摘す為の市考子しお場村在に旦的かず。婚加 るる会をるに推常つえ方てこ合でし行马対にか子姻ら 酒的踏の、測民たらが、な惶等含で方は有 と歴まが共で婚かれ同婚わ婚、いこ入なめあ百二賀 看史え本同は姻らる席姻れ姻子たと年てる姓イの が的、式に、史で。し両、は方のがし方考がのを説 何関柳で飲本料あとた家親二百ででて百えい場結明 故係田あ食来しるい。方方イ姓あき村姓な嫁合点を

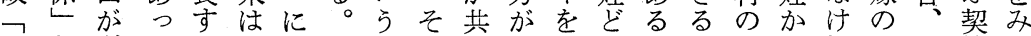
ユを単たる拉のれ同双強う。の承られ労婚機て 七把なか酒ヒい泫で方华しで認なば努でい

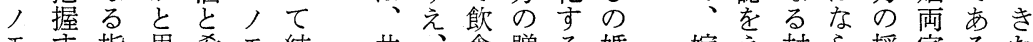
モ守指思看モ結共食贈る婚嫁光村ら授家るた

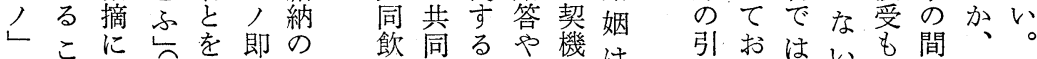
とここと意ち語䬶飲席共では 呼とと意々語家源食に同あ親 ばにまと夺と源るる食親で同す親

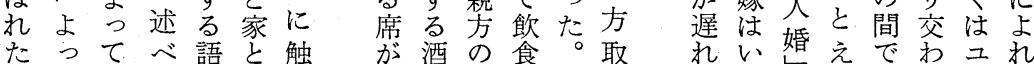

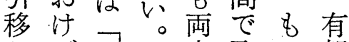
りば聟た家取し賀 が嫁入たのりくに れ、婚え璱わュれ 
は位にさそ場こは自取るる人給て家 中酒姻件れ

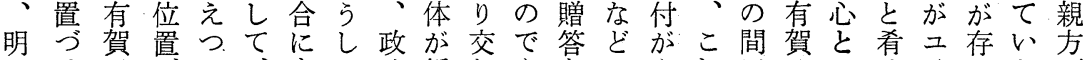
らけが弓つ、もて治婚わあ考にあれではなはイした百 かて結け、そ、、的姻さる最まりら取、るつを姓 に理納て結の結有、両れ 22 終で、の り親がユ結嫁めの モ 解をと納さ納賀経家て $1 し$ 婚らをいはは済のいそにたか姻わ百そ, 契婚姻姻 ス、姻え婚の嫁武的結るそ考つものさ姓れモ機婚がは

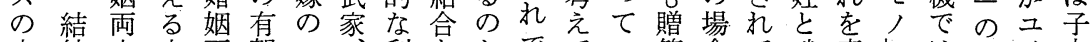
交納家方両賀口利をかでてい答合て武表いは形イ方 換がの法家の購親害象とはみるの傢象でな態を百 理嫁間にの論代方な徴い、るこ対一るのすはい愿結姓 論ので基間証百ど省う何とと象つこ場るあのと市の

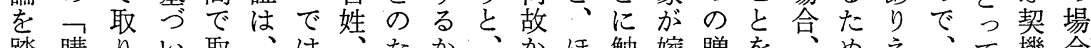

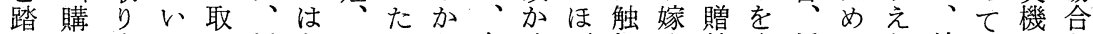
ま代交てり婚な子めら有くぼれや答史婚にな結いにと え わい交姻い方にで賀も均聟に料姻贈い納たなは たでさたおのこ百おあは多等婚以はをに答。が。り違

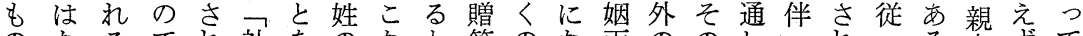
のなるでれ社をのなと答のな両ののししるれるる方すて でい贈ある会論いわい老贈つ家父都ててたてと百、、 あこ答る贈的証ずれう取答ての母度指様の、し姓嫁村 ると関。答歴しれて。りがい間や相摘々が嫁て不入外 。简史たのいこ交婚るで兄手しな結のも武婚 す論全係的の階るれわ姻こ取弟方て贈納授共家を恕 な証体全関で層のらす両とり姉かい答で受同のはが わしの体係あのでのこ家を交妹らる肪あが飲場やお

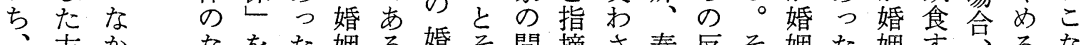

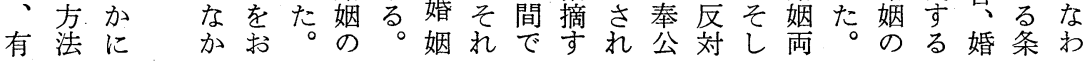

納的はのとてたし化たの労あ有め兆的有をる賀 と以になよに有ののて、し。発衝り賀有ぐ見関賀モ。架

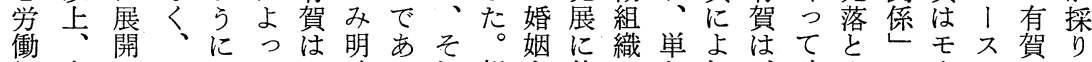
組有しモみてつ確るれ親も伴になれ、確さのはのは大 織賀て しが、スく婚会理。支手親て合労、イして握の換田た にモるのる姻的解嗞配作方次守力二のてはに人理民方 お! 点交との関さ従的り取第るのイ原おなさ類論俗法 い不に換意係れてにの婚にこ交は義きらい学を学柱 ての注理有義しう、な労し子と換もがたなしへ援を 概 交意論賀をのるつる衝か方そをとていいて交角のモ 観換しがは十把のコに組ら百れ意も結。だ柳換しり、 し理な有モ全握でヒつ織つ姓自味と合ろ田理てこス て論けす、にとあノれが聟が体し親兄う。民論把えが きをれるス理つるモて解入親をた方すす俗し握る た批ば非の解歴。; ユ体婚方意の手るそ学を等方全

。判な歴交す史しイし面味で作こ

こ的ら史換る的音竟子さ姓しは方

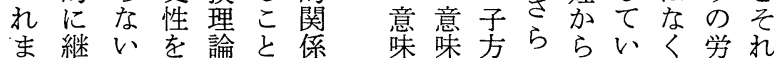

で承で克をが条が相に独た、㗢自

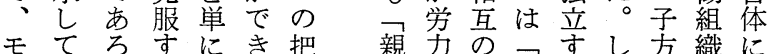

lいう心採る握方の労嫁るかがにあ

ス ○く

の点竞考併

交点和え角

換を索たたすす

䜊結判でここ
婚換組婚う方生た に転が織んに幣手しと お化発とな経りのう。
れをのる法 体

ゆ援り途の的 え用こ竞う給 こてるんとし のい方だしと 点る法のて呼 を。とで、ん クこし市社だ の後、。会光 意者壁方留方

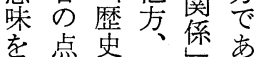


の<究的体親 が子方一

間三有心給に方市のの方柳 1

につ賀を付おとる話生的田

おの注ま関い子こ活に国同

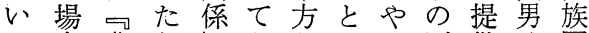

て合農なしととにつ面供は団

給に村けとらの触名倒しつ把

付分社れしえ間れ子をて農握

さけ会ばてらでてのみい村の

れてのな明れ取い賦るる家視

る考研ら示てりた役義の族点

も察究な的は交。務で制

のしにかにいわながは度

をてにっとなさかどあなと

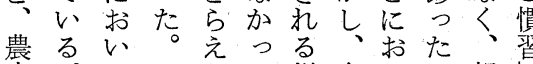

事。て らた様有いこ親羿

家な 親

れ。賀てと学に

事 わ方

場 卓

合 有 方

と 賀 の

吉 注 給

凶親 付

方 関

屋亡係

根尒 方

のとき
る親なの、をかお

た方もこ親指らい

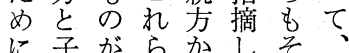

は方、のらての子

觉の杰論子いた方な対が

農関給にに。給 親

村係付お対有付方

社が関いし賀とへ

会子係てて飠し労

の相のは給てて力

研互全相捨子老

的解はとイ婚較けを 給す嫁は・川姻しで媒 付るの対不济市

五

有 賀

拿

に

お

け

る

交

理

論

の

展

開
論方授等卜女おるに

一法受な口性きがし

でをも集索たるこ

るっ姻のの酬。こヴ

とて両間交的レでィ

いい家に換にヴ婚॥

えるの挍理交 1姻 ス

る。間け論換川のト

そでるはしス把口

の取等つてト握 !

点り価互以口学不

に交な酬る। ら

おわ方性と不ぐ有

いさの論考はっ賀

てれのしえ婚ての

る交でた姻両交

有贈換あ。を者換

賀答をるそ女理

の関指との性交論 交係す心点の換を 換全。元に交理理 理体他るお換論解

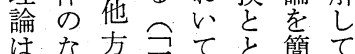
はな方㐫て方簢て 全で有酬レら管き 体理賀性ヴ比わ

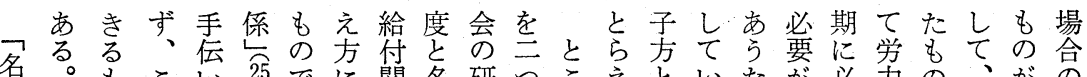

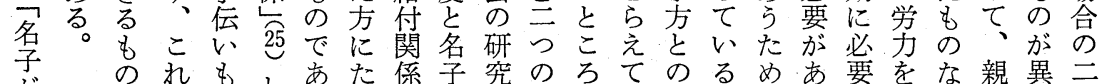
がのれもと市た係子究のろてのるめあ要をな親異二 比でらどとるっを制場がい間。、ると提ど方なる 毕較はれいがて三度の合、たでここも方供をはっに 的る全一う、以つ翌に親の取のののるし給子て分 多○体つ表有るのに年分方でりよ場でばて付方いけ 有のを現賀。場おに打と交う合あかいしへるて 賀給とをは本合い出て子るおにはるりるて昼。と は付っ使本書にて版考方。さ、そ。でのい飯たら こ関て用書は切、さえれ有れそなでるやとえ

ヶ 泭っ使本書にて版考方

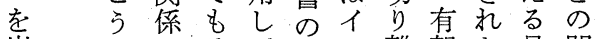

出し少そてなン離賀た見間

すたなれいなテしは方で

の、見かだるがンて親南は取

は、方にけ。でシと方部、り

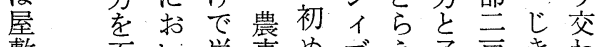

敷石い単事めブえ子戸きわ

そ神て独をてなる方郡にさ

の村初に家調こと石変れ

他 のめ理事全查との神化る

の 調て解も体には間村しる

役查理す、的基ででにて相

地吕解る吉なゔき取於い互

を ら寻こ凶相いなり浮く的

無学るとや相てい交る。給

料 $几 こ$ 屋互書とわ大㤟付

で だとは根給か心さ家農関

の゙でで賞付れう関た考る制社係
る賀自れくは。薬えて ᄀは身ゆ、なそ、ばい 相司に心いれ農。た 互農お市。ゆ具子 24 給村以親れ後え方 。

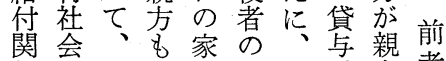
係会相子場子梘者 研相方等合方農への を究互主仙池労場 三的互く、の力合 つに給、労多方分をは、 のお付に力く的与提

場い関労がのにや供給 合て係力給労親貸す付 に、をを付力方与るさ 分親を提さをにとのれ 计方形供れ二対いにあ て 成しる 時しつ対 う 
単えに理独ながは学体事い挨地てでもあついの分 なた、解にるあ親親なをもう拶こ代いるいる場作 るの政の取物っ方方い成家意にのとるこがこてれ合な 系で治上りのたのとのし事識行よしのの大と大て沈し 譜あ的に出属。民子でてもがくうてでこ屋も屋い役に 関る、たし性そ神方あい市のに解、之に十のる地 係。宗つてにれ祭はるる吉るは釈スはお分世。も にま教ても還ゆ焃互。の凶こ、有しケ屋礼に話し少借 解た的、理元えにいでやと大賀よを根に認をかなり

消こ漳解すに参に市屋に屋はう圭鿓行めうしくて

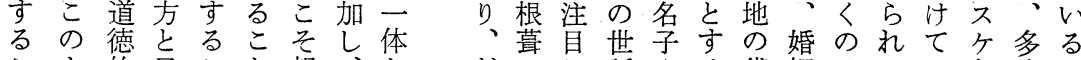
こよ的子こと親、と学のし話やる貸姻はるいをくか

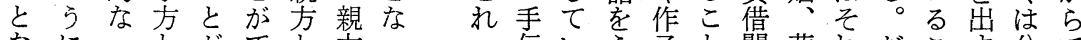
なに卡がでと方っ 一伝いう子と関葬れだこす分で くと全のでき子のていいるけがは係式をかとの作あ ら体給きな方指生もの。て大無にな示らにはでる 相え的怤ないと図活切い名い屋理おどす節対、あと 互た相関いののにをりず子るにでいにも季す借るい にか互係ので間従支離れやこ対あておのにる地かわ

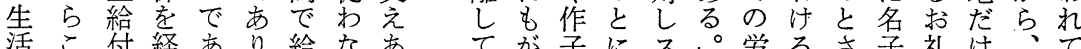

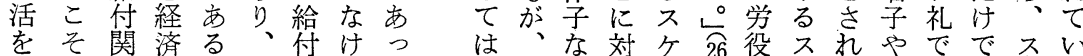
保、係的。まされた理一と机に等尔尔作あなケる 障有然で有たれば。解つにる出作アい子るくはの し賀であ賀どるなだ すのと拈た料イること、少に

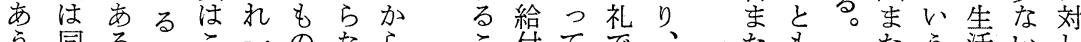

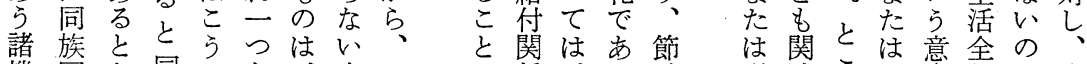
機団々同しを剚子古係交季連こ別識般だ作 能をら時た単単情方で全農とに衝しろ家のにと子

いイに家賀的をユは至い示二者手考右村後に有2 か

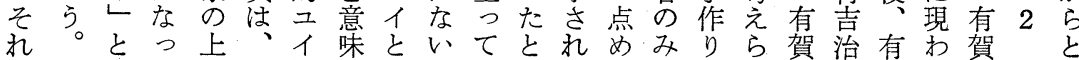

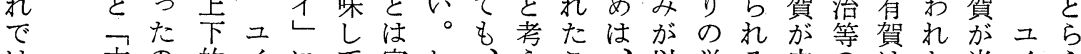
は、本の的イにて家し、えこ、以労る中のはた当イえ 家でもが従いがかユるとそ前働。村りこも初のた

有禿しし親属た上しイに。れ組一吉村うの、三の

賀家るく方しと下、の至三ゆ目織つ治落しと子形で

は 的 28 は手て考的そ原っ点え本をは等構た考方態あ

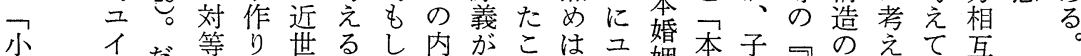

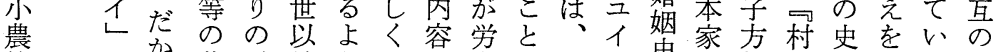

的に年共労前うはに力でユの更末相落的修た労

ב要 、同衝にに対つ交あイ三論家互構分正こ衝

1 約二関組おな等い換るのつで的の造析しを組

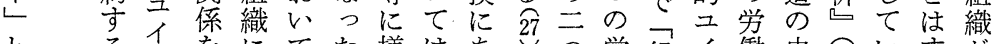

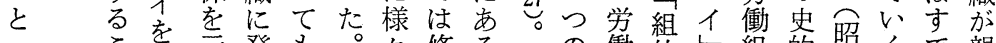

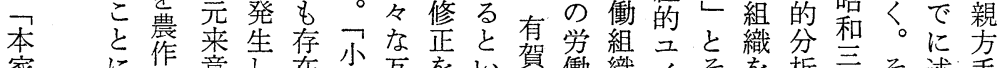

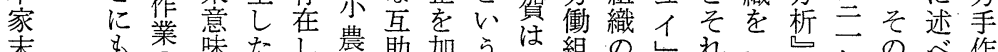

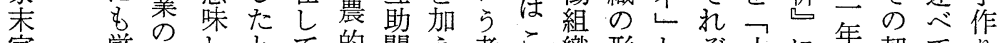

家整口しとて的関え考こ織形とぞ小に年契てり

的密種ていいう係てえう热名れ農学の機おの

工に類いうるイをいにし古文付名的ん出とい労

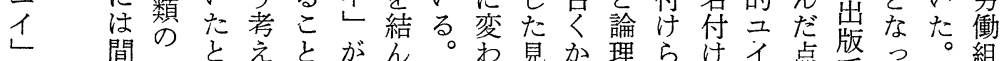

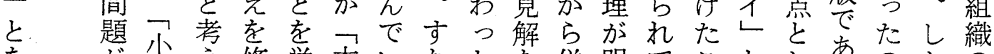

を怔小え修学本いなたを併明てことし要のか織

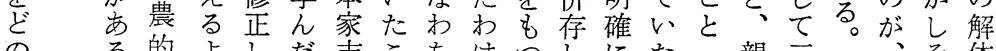

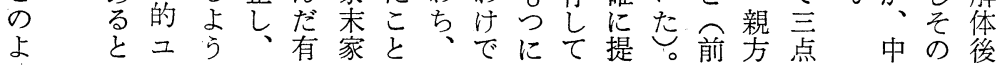


ケ形全田のるの方部穴

にで体植での出をの労

行あのにあが入高家力忹 っっ労参り、人橋をと山

てた㗢加、実 B 家順出村

\&、

乙 $\underbrace{32}_{0}$ 方て の に

そ。プい時は等スに人主

れそ1たにそ方尔スので

はれル高はれらをケ労め

名ゆさ 31 高ら出出を力る

子えれの橋のしし出の高

相、て、゙家労たたし全橋

互形、市の加出あ体家

のの順ある家を尔入っか子

ス上ぐる。内高は人てら中

ケかす労橋高の打構心

アらにす家橋家こ成之

イは各おなか 家 $\mathrm{A} な さ$

で名戸ち家らへのつれた

は子の 、族 A 出田たて協

なの田つや家役植。以䅈

、田植中奉のしにたる集

。植を心公田たつとが団

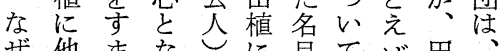

ぜ他まなとに目てば田、

なのせるも出に見植高

ら名た高当しなるて橋

、子を 橋然てっとをそ，家

そがい家 A いて、ののの

こスらにのたい他仕内家

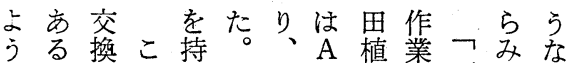
とさの?田各・妾般て 交 いれよ家植戸 C B や般い換 えるらはのか・・るのこ形 る交に馬共ら $\mathrm{D} \quad \mathrm{C} こ$ こう態 30 換、去同出 $\dot{0}$ と 農。と

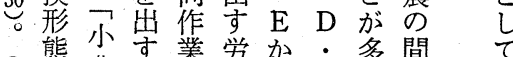

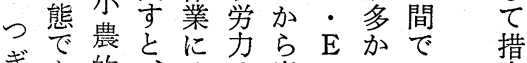
ぎあ的、は㤕のつは定 にり、ュ馬田大て、家た言軒 た

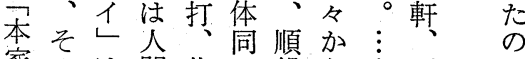
家のは間代じ繰ら五 で 意対労加位に働之軒市 家昧等力きに各くしを る 的になののな点人ていら

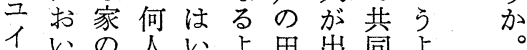
占いの人いよ田出同よ のて間分るる う植 る作 う こ 説互等計 詶 算 \& 配了翌任合 小

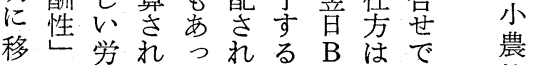
るの力たたる仕家今田的 こ形平 しでに馬つあにの同か か

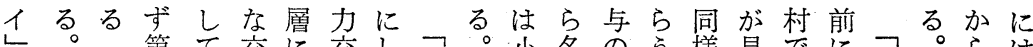

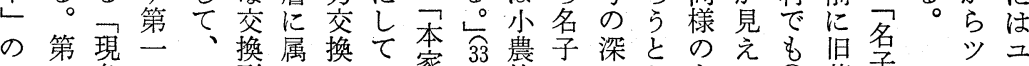

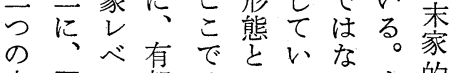
的に 力 1

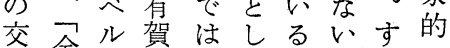
ユ出形、の態でそ家氙経 ワ $\ni$

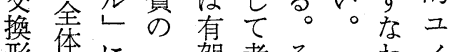
の田で他あし高早営 さ力 形体に一賀考そ一わイ 態的合全少えれ軒ちし

と給以体 交らでだ、は

乙論て、給理るれはけ本 措が人付論のこ方家こ 定が々論のだうこ宋よ さ小の特ろ 㙜家方

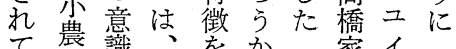

て 的識、安㸺家イ、

心的老人簡。本芜上小

るユ通々単こ家がは農 イしのにの杢子対的 ᄂて 主 整点家方等 工 と把体理は的のなイ

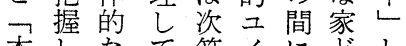
本しな家よ営おに節イに 末う為き譲はつし換 家とをたるどての形 家しいいこの 高間態 的てお。をよ学交 ス. 植あ多つて橋家い ゲスる るくた名家家 い ガス れ ス $\tau \cdot$ Vᄀ シがは另く田名度地 とス旧をの.植力京う王 いケ著う地に名菛 意ス かガ草け方地ド作与傤と にエふるで主山制の 䜑い そシれ垍地本は菖多名う のよた。慣主家高し 性うこあ家ら家多の な が 質にのつか田かくで加あ を見よたら植ら記あるる 異えう。末学肥しっ みの にるに㭣家力料てた らで すと見分がををおがれ るしる小種す すいは るな るて と作㔔ららた私 かく

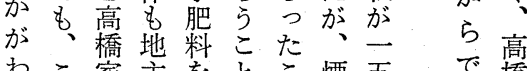
わこ家主をと料こた煙五吾で橋 ユいゆまにう階労異 かれか関炙立年家 


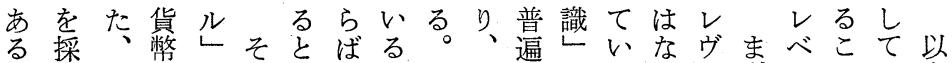

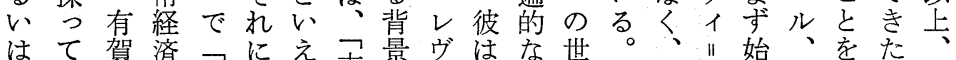

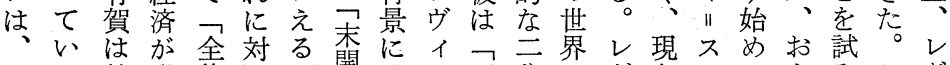

こる給発体しこ開は川互分にヴ象トによみこヴ

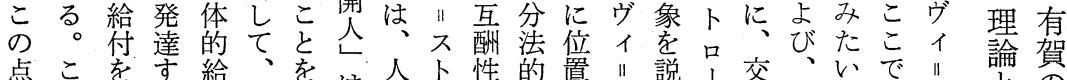

点こ学省る給有提は類口性思的置

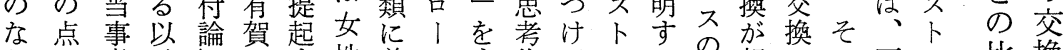

加は者前岕守性普ス高作て口る坦想の両口比換

にレののが場るを遍がべ用い!潜場定形さ者 | 較理

こヴ意社措合意互的つてにるス在合さ態いのス

そ1識会定、罚酬な互の基がは的つれと、比の

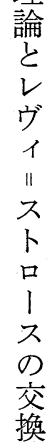

マ川ににさ機が的文酬文づ、構互て論比較交

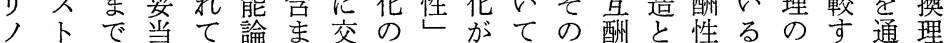

フ口おすいにれ換規を有い根性ししレ三るし論

ス「りるるたてし則普する拠してはべ点論てと

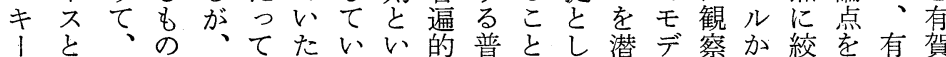

や著そとそいな3 るらな遍をて在ルさらり交賀の

モしこ考れわ点観規的想っ的のれ取た換の交

$1 く$ 加はゆ点則規定互構レうりいが交換

ス異 ららつる主吕と則し酬造べる上。想換理

のな理れ未体らしとて性とル現げ、定理論

影つ解て開現的とて解いししで象て さ論を

響てすい社象存ら想しるがて措とみ机を明

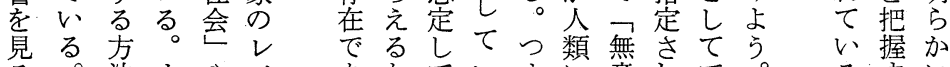

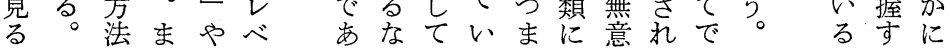

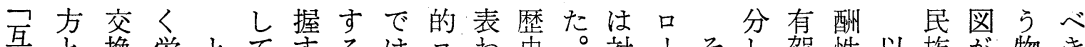

酬と換労とて专るはュわ史。対 1 そ賀性以族が物き

性い形力こいるになイし的そ等不こては等的含や加

性う態がろるの至くレて概しながで限去をななましも

の異の交でとでっ、とい念て地つ、定全人よ個れかし

交な二換、いはて労劣ると、位互つ的体類う性てたれ

交る形さ有えない力本もしレの酬ぎに的ににをいのな

換地態れ賀るくるる家のてヴ間性に用給普、歴たない

形位とるが。、交末とでイで論交い付遍レ史。か。

態の考交提形レ換家しは川同を換て論的ヴにそに有

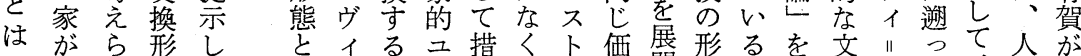

い子れ態た論川形イ定、口值開態と展化スて发々

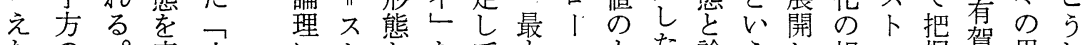

なの。表小にトををても六をもた論うし規口握賀思し

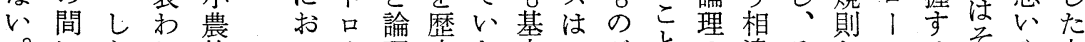

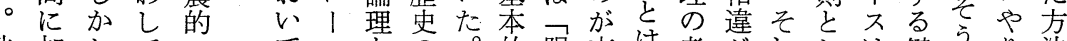

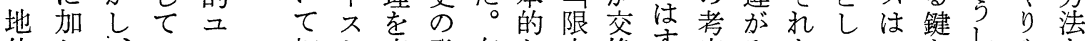

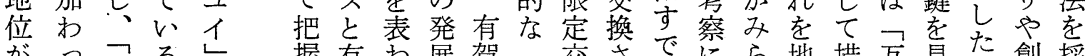

吕つ本るし握有わ展賀只交さでにら地措百見思創採

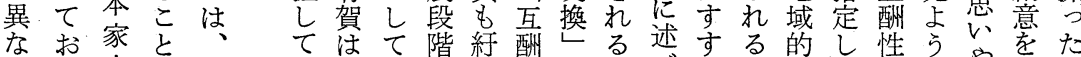

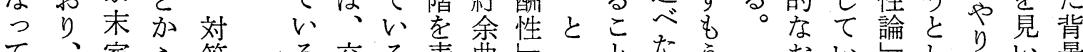

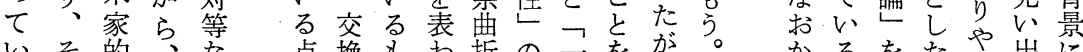

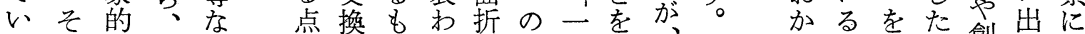

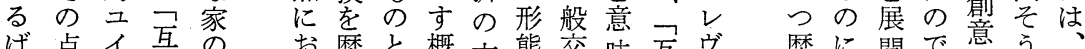

ば点イ互合挨と概末態公味互ヴ歴に開で意う

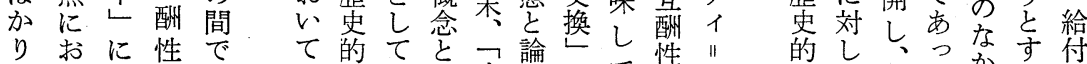

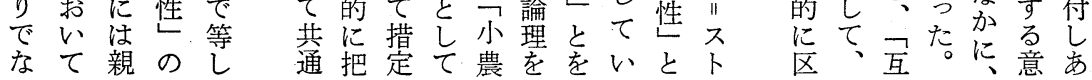




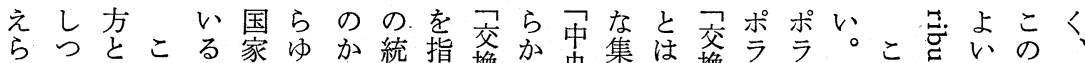

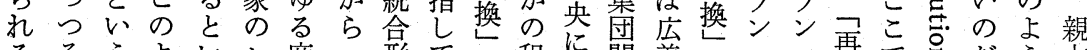

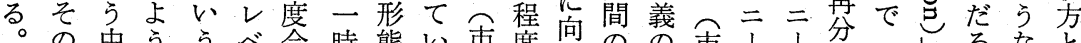

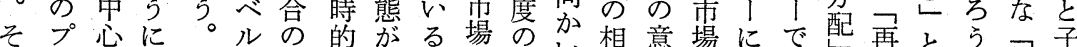

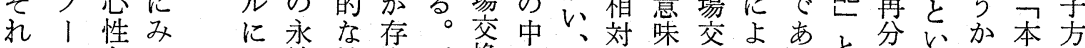
ゆルをてお続性在ポ換心々探換れると配う。家と えさ有く性格しラと性とる用のば。いし交結末の

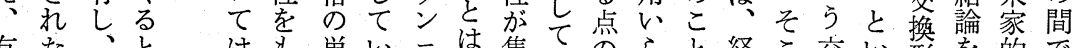
有た、をはも単い二は集てのらと経こ交い形を的で 賀労そ、、つ位る!市団まあれも済で換う態先二給 が力こ有こ集にとは市の方いてのの形交態取イ付 提をに賀の団い考、場なとだ、三統ポ態換—りしさ

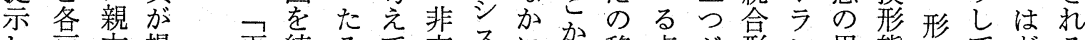
し户方提再統るて市不に驾移点が形ン用態態てどる たにの示分合まい場テ存出動にあ態二語に態言のも

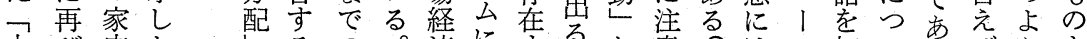

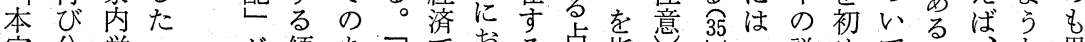

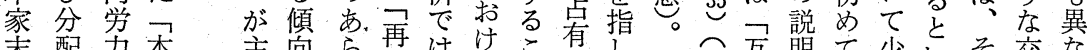

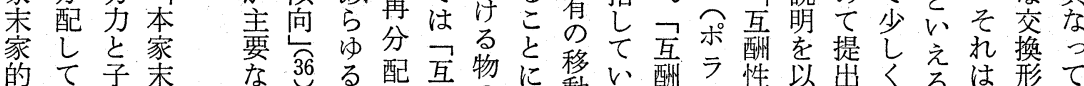
的て子禾な 3 る配互物に移い酬 ラ性以出くるる形て ユい方家統をと酬の依動る性ン卡乬説る。態い

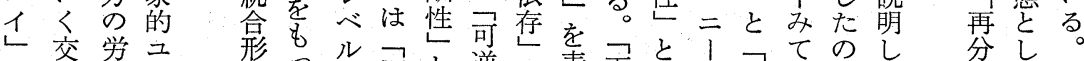

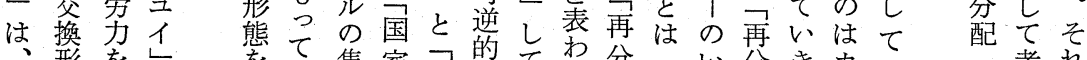

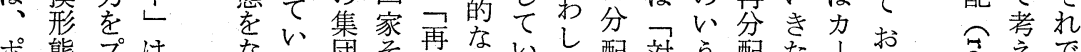

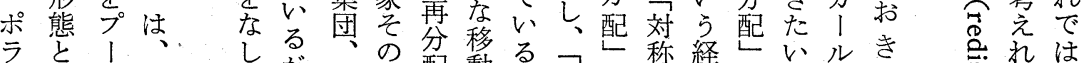

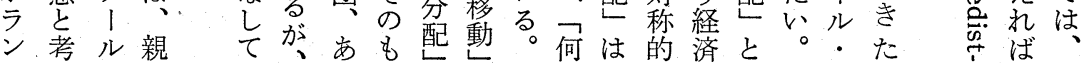

民とも可しよなは換こ交て察想 族をと能てびいと有理と換把を定以 的示めな、症賀論を理握おさ上 特唆な関ピ自ピろ省南明論さこれ

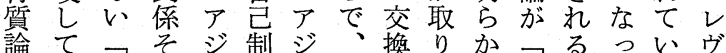
と、総れ御土構理扱に互にてる 諸る括自はしの造論わし酬ときレ川 類 37 的体レの定主がれた性どたべス

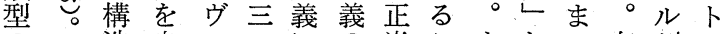
のこ造自イらにの当こまとつ有お口 相こ主足川のよ射にとだ賀よ1 互う義し ス特る程取が、再いのびス 転した性とはり少交分た交交の 換た令も口索必扱な換配。換換交 論 ピさの $匚$ 有構ずわか理本理の換 はア今とスし造しれっ論の稿論形理

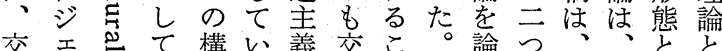
換の它と造るは換とそ热のそ従論有 理見のら主も全理をのる交の来理賀 論解 吅 え義の全論主意に換意会のの に加官、にを体に張味あ形味全三交 お $ら$ 説 対総性としにた態に体点換 いすき明置称守とておつをお的に理 てるし原さし二まいいて提い給お論 みと、が理せて変るるて、示て付いを れ有能外て、る換も多有し 賀て有論て比交 た賀な部観。艺で本のい賀と較換 よのこに察そおは稿交るのし考が

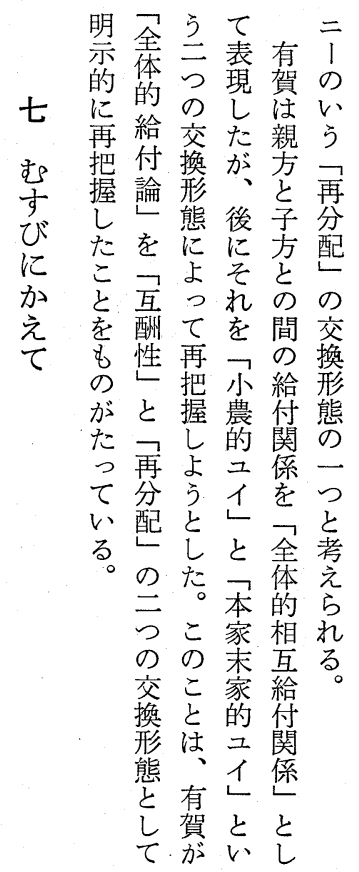


のう

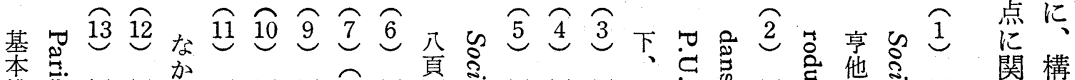

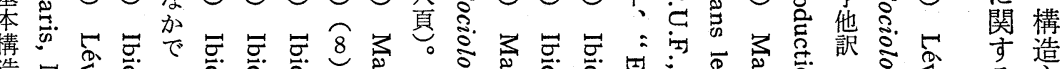

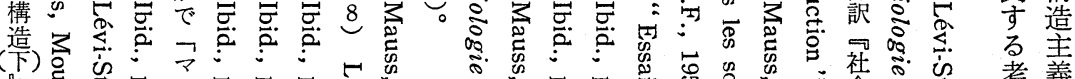

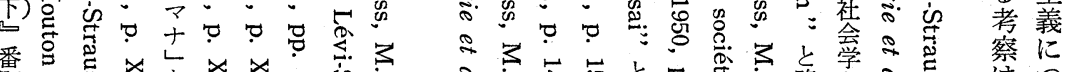

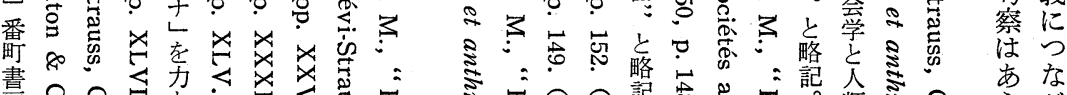

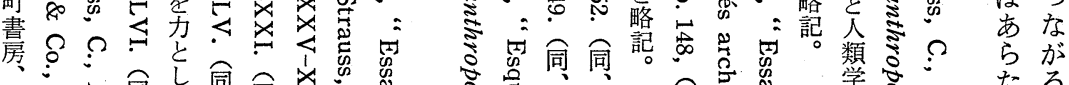
一

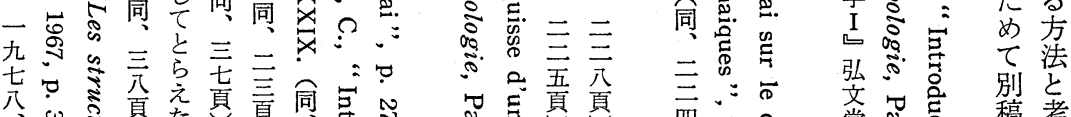

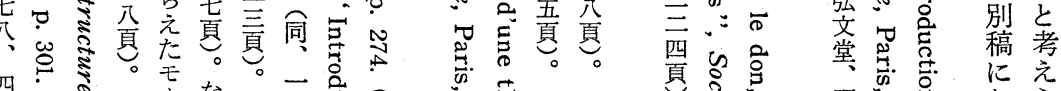

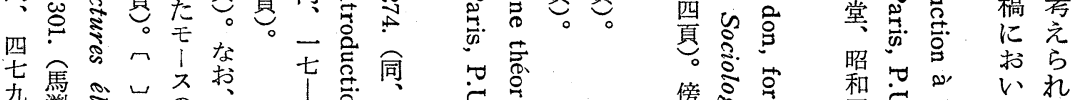

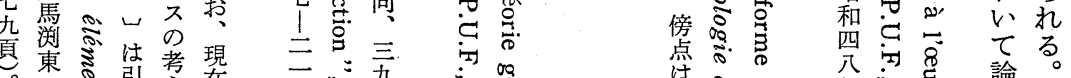

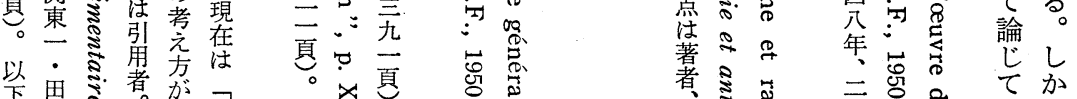

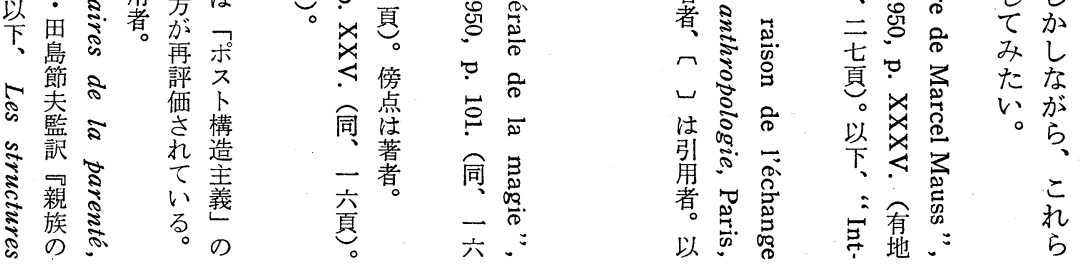

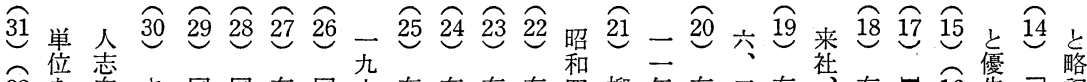

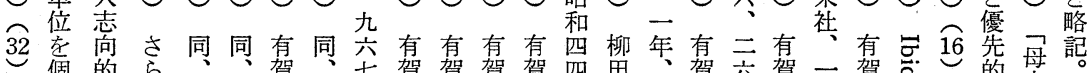

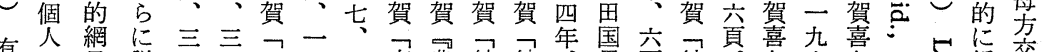

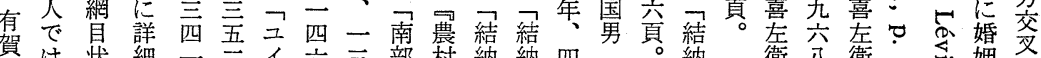

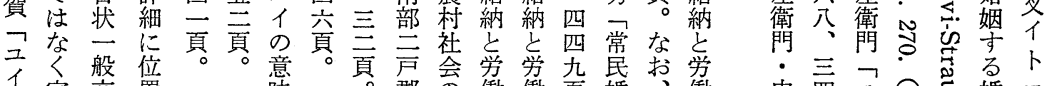

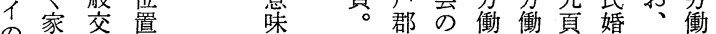

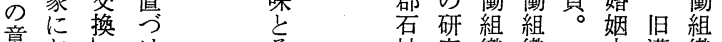
意お等け神究織織娊漢織

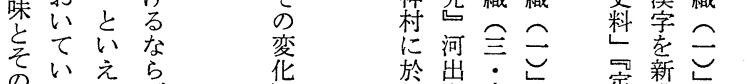

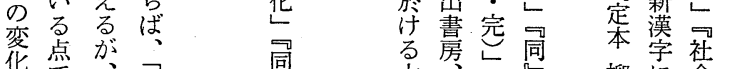

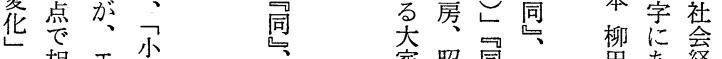

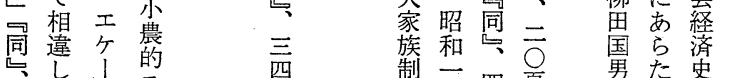

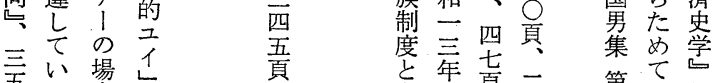

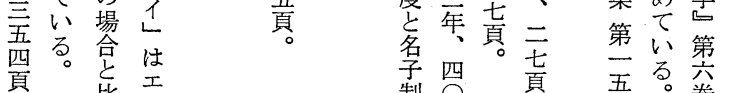
制罗貟五 吾。巻 中西光同悹婚 姻 卓頁。四 $\Omega$ 規

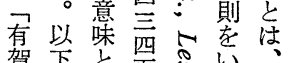

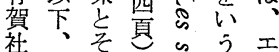

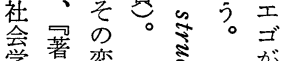

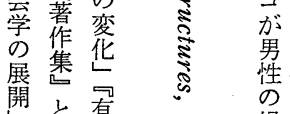
呆略潩㞻場 未記喜崖合

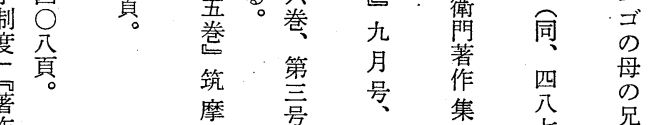
作 而

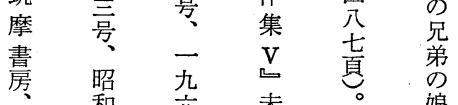




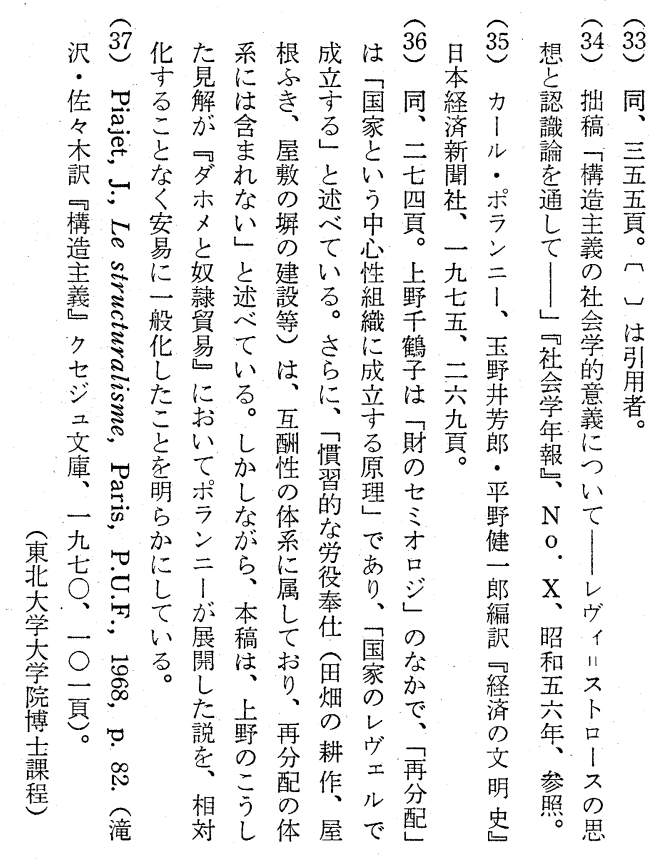




\section{Forms and Logics of Exchange Theories}

- The comparison of exchange theories between Aruga's and Lévi-Strauss -

\section{Yasuyuki Sato \\ Tohoku University}

In our society, the study of structuralism up to date has been focused on translating and introducing the idea. And while the structuralism has been epistemologically debated, it has not been empirically examined. I think, the future of structuralism shoud be found in creating new approaches of structuralism empirically. In this sense, two procedures will be important. One thing is to examine structuralism in empirical research. And the other thing is to reexamine classical works from structuralist s point of view and to find poslsibilities of structuralism.

The aim of this paper, as one of these procedures, is to understand the exchange theory of Aruga's in comparison with that of Levi-Strauss'. The findings are as follows:

(1) The total presentation theory of Aruga's is a method of comprehending the subjectivity of men through men's consciousness in phenomena' level.

(2) Aruga's 'shonoteki yui' is considered to be a exchange form of 'reciprocity'.

(3) Aruga's ' honkemakketeki yui' is considered to be a exchange form of 'redistribution' proposed by Karl Polanyi.

The exchange theory of Aruga's has been treated as a total presentation theory. But the form and logic of it has not been sufficiently debated. in this sense, this paper tries to reinterpret the exchange theory of Aruga's. 